\title{
Characterization and Typology of Aghien Lagoon waters (South- East of Cote d'Ivoire): Potential Resources for Drinking Water Production
}

\author{
Lydie Nina Amon ${ }^{1,2}$, Léon Koffi Konan ${ }^{1 *}$, Safiatou Coulibaly ${ }^{3}$, Jonas Yapi yapo \\ Andji ${ }^{1}$, Julien kalpy Coulibaly ${ }^{2}$, Samuel Oyetola ${ }^{1}$, Mireille Dosso ${ }^{2}$ \\ ${ }^{I}$ Laboratoire de Chimie des Matériaux Inorganiques (LCMI), Université Félix Houphouët-Boigny, Cocody- \\ Abidjan, UFR SSMT,22 BP 582 Abidjan 22 (Côte d'Ivoire) \\ ${ }^{2}$ Unité de Chimie et de Microbiologie Environnementale, Institut Pasteur de Côte d'Ivoire (IPCI), 01 BP 490 \\ Abidjan 01 \\ ${ }^{3}$ Centre de Recherches Océanologiques, 22 BP 973 Abidjan 22
}

\begin{abstract}
The objective of this study was to evaluate the physico-chemical quality of the Aghien lagoon in view of its consomptions as drinking water. The physico-chemical parameters were measured and water sampling were carried out monthly from June 2014 to May 2015 in eleven (11) sites well defined around Aghien lagoon. The parameters were determined using standard methods as defined by the French Association of Standardization (AFNOR). The Seasonal values of temperature, $\mathrm{pH}$, turbidity, electrical conductivity, percentage dissolved oxygen and TSS in Water,falls to the following 26.31-29.76 ${ }^{\circ} \mathrm{C}$; 6.95-8.03; 16.74-41.05 NTU; 63.15-109.11 $\mu \mathrm{S} / \mathrm{Cm}$; 63.91-100.21\% and 8-31.18 mg/L respectively. ANOVA analysis result showed no significant differences ( $p>0.05$ ) between seasons (dry and rainy) as for temperature, $p H$ and electrical conductivity in all stations. For turbidity, dissolved oxygen and TSS, there was a significant difference between seasons. Seasonal concentrations of nutrient salts in water $(\mathrm{mg} / \mathrm{L})$ ranged from 0.01 to 0.14 for $\mathrm{NO}_{2}{ }_{2} ; 0.48$ and 1.93 for $\mathrm{NO}_{3}{ }_{3}^{-} ; 0.06$ and 1.90 for $\mathrm{PO}_{4}{ }^{3-}$. Seasonal variations showed a significant difference $(p<0.05)$ for nitrate. The mean values of most parameters studied during both seasons are generally below the standard values recommended by the World Health Organization and SEQ Littoral. The calculated COD / BOD $D_{5}$ ratio showed that the water in the Aghien Lagoon is rich in biodegradable organic matter. The principal component analysis (P.C.A) of the data allowed to define three different types of water of the Aghien lagoon influenced by the seasonal variables. On the whole, the waters of the Aghien Lagoon could be used for the production of drinking water after treatment.
\end{abstract}

Keywords: Physico-chemical parameters, Typology, Water resources, Aghien Lagoon,

\section{Introduction}

One of the major issues cpncerning the future of mankind is the availability of quality water that has become even more precious than oil [1, 2]. In many developing countries, at least 1.1 billion people lack access to safe drinking water, leading to several million deaths a year, especially among children in poor countries in Asia and Africa [3 ]. In addition, the recent report of the United Nations Environment Program (UNEP) drescribed a very worrying situation of the future of water resources, particularly in Africa [4]. As a result, the Millennium Development Goals has been to reduce by halve the proportion of the world population deprived of safe drinking water. Across the world, groundwater is being subjected daily to excessive pressure. These natural reservoirs, which contain nearly one third of the world's freshwater reserves, are overexploited in some parts of the world for the needs of populations, industry and agricultural purposes [5]. The level of groundwater is declining everywhere and in consequence the lives of about 1.5 billion inhabitants of the planet [6] are threatened.

In Côte d'Ivoire, the demand for drinking water by the Ivorian population is in perpetual increase far exceeding the available supply [7]. In the district of Abidjan, current drinking water requirements are estimated at 170 million cubic meters / year, while the maximum allowable water withdrawal volume is 130 million cubic meters [8]. In view of the increasing population growth and the depletion of groundwater, it is necessary to use other freshwater resources that could be used to meet the drinking water needs of the population of District of Abidjan. It is in this context that the Aghien lagoon, a surface freshwater reserve, fed by the Djibi and Bété rivers, located to the east of Abidjan, has been identified as a potential resource. The present work proposes to evaluate the typology of the waters of the Aghien lagoon through a physic-chemical characterization with the intention to highlight its usefulness as an additional drinking water resource. 


\subsection{Study area}

\section{Experimentation}

The Aghien lagoon is situated in the southeastern part of Côte d'Ivoire on the slope of the Comoé river between latitudes $\mathrm{N} 05^{\circ} 22$ 'and $\mathrm{N} 05^{\circ} 26^{\prime}$ and longitudes W $003^{\circ} 49$ 'and W $003^{\circ} 55^{\prime}$ (Fig. 1). With an area of $20 \mathrm{~km}^{2}$ and a volume of $25 \mathrm{~km}^{3}$, the Aghien lagoon is fed by two main tributaries, the Djibi and Bétérivers. It communicates with the Potou lagoon by a natural channel into which the water flows from the Me river flow.With an equatorial climate, the Aghien lagoon is characterized by rainy season (April - July, October and November) and dry season (December - March, August and September). The vegetation is a dense evergreen and rainforest type, which favors anthropogenic activities, especially cash crops.The study area is marked by two geological units, the sedimentary formations of which are located to the south and the formations of the crystalline and crystallophyllian basement situated in the extreme north. The sedimentary formations consist of detrital rocks of the Tertiary and Quaternary. The sedimentary basin, which occupies most of the area, consists of sands and Quaternary vases on the eastern edge of the Aghien Lagoon and along the Mériver. The sand, clays and sandstones of the Continental Terminal are the most abundant. The formations of the crystalline and crystallophyllian basement are composed of fine biotite and amphibole gneiss[9]. Two types of aquifers are found in the Aghien zone, in particular the continuous aquifers of the sedimentary basin and the discontinuous aquifers of the basement. The various sampling stations were chosen based on Humbert's[10] work (Fig. 1). The stations were identified using a MLR SP 12X GPS (Table I).
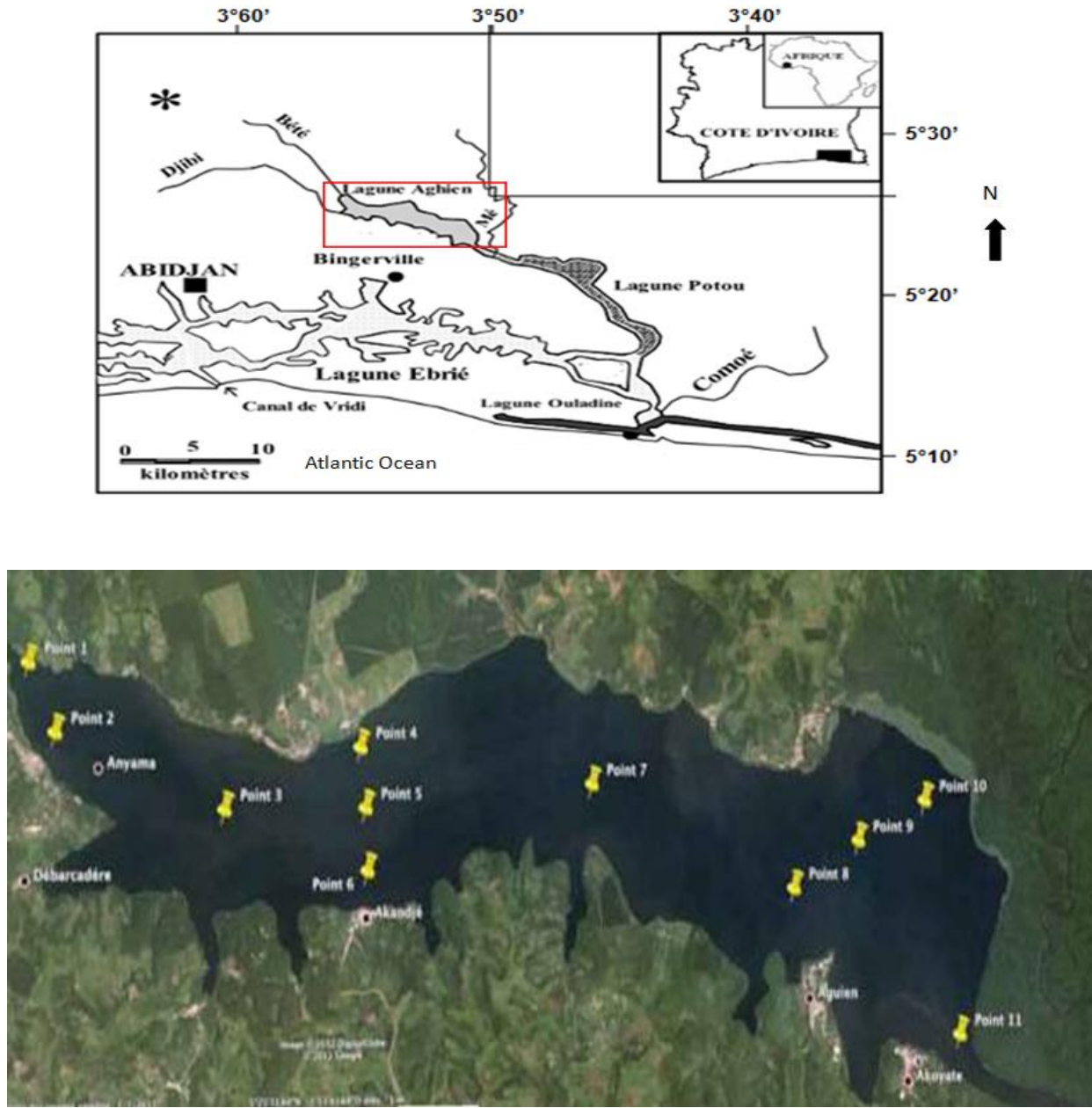

Fig.1: Sampling stations locations on Aghien lagoon, Côte d'Ivoire,Sampling stations (S1-S2-S3-S4-S5-S6-S7S8-S9-S10-S11) 
Table I: Geographical coordinates of sampling stations

\begin{tabular}{|c|c|}
\hline SamplingStations & GeographicalCoordinates \\
\hline S1 & 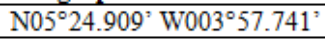 \\
\hline $\mathrm{S} 2$ & 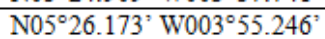 \\
\hline S3 & 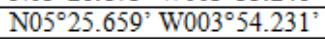 \\
\hline S4 & 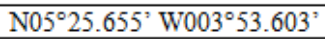 \\
\hline S5 & 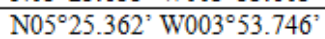 \\
\hline S6 & 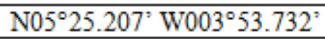 \\
\hline S7 & 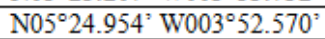 \\
\hline S8 & 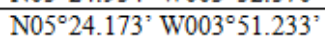 \\
\hline S9 & 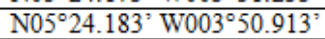 \\
\hline S10 & 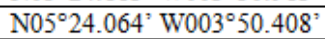 \\
\hline S11 & 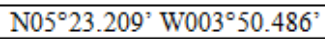 \\
\hline
\end{tabular}

\subsection{Sampling and analysis method}

Measurements of physico-chemical parameters and the sampling of water were carried out monthly from June 2014 to May 2015 in well defined eleven (11) sites around the Aghien lagoon. Temperature, $\mathrm{pH}$, electrical conductivity and turbidity were determined in situ using a Wagtech portable multiparameter probe. The percentage of dissolved oxygen was quantified using a WTW type oximeter (OXY 340i). The suspended solids (MES) were determined by filtration of a $200 \mathrm{ml}$ volume of water on a cellulosic filter of $0.45 \mu \mathrm{m}$ according to the method as described by Rodier[11].

The orthophosphate, nitrite and nitrate were measured using a $\mathrm{HACH}$ molecular absorption spectrophotometer according to Murphy and Riley [12]. Phosphates, nitrites and nitrates were measured at waves of $885 \mathrm{~nm}, 543 \mathrm{~nm}$ and $415 \mathrm{~nm}$ respectively. The chemical oxygen demand (COD) was determined by the potassium dichromate method according to the frenchstandard AFNOR standard NF T90-101-2001[13]. The biochemical oxygen demand for 5 days $\left(\mathrm{BOD}_{5}\right)$ was determined by the respirometric method using an oxitop according to the APHA standard[14]. The ratio COD / $\mathrm{BOD}_{5}$ were calculated to determine the quality of water from the different stations. ANOVA analysis was used to determine the differences in parameters between dry seasons and rainy season. The differences were considered significant at $\mathrm{p}<0.05$. The Principal Component Analysis (PCA) was used to determine the typology of the Aghien Lagoon.

\section{1- Physico-chemical parameters}

\section{Results And Discussion}

The seasonal values of physico-chemical parameters (temperature, $\mathrm{pH}$, turbidity, conductivity, TSS and dissolved oxygen) measured from June 2014 to May 2015 in the water of the Aghien lagoon are presented in Table II. The seasonal temperature was high in all stations. It varies from $26.32 \pm 3.92$ to $29.77 \pm 3.56{ }^{\circ} \mathrm{C}$. The highest temperatures were recorded during the dry season and the lowest during the rainy season. This variation seems to depend on the degree of sunshine, precipitation, wind and vegetation on one hand, and on the other hand, the temperature of the air [15-17]. According to Moussa Moumouni Djermakoye [18], the increase in temperature favors the phenomenon of self-purification and increases the rate of sedimentation of the suspended matter which is very interesting for the production of drinking water. The waters of the Aghien lagoon have a basic character in all stations and during all seasons except at station $\mathrm{S} 8$ where water $\mathrm{pH}$ was acidic $(6.95 \pm$ $0.67)$ during the dry season. The highest $\mathrm{pH}$ value $(8.03 \pm 1.17)$ was recorded at station $\mathrm{S} 9$ during the rainy season. Since the Aghien lagoon has no marine influence, this alkaline character could be explained due to biological and physico-chemical reactions due to the presence of aquatic plants [19]. Seasonal conductivity remains low in all stations in all seasons. It varies between $63.1 \pm 29.93$ and $109.11 \pm 65.22 \mu \mathrm{S} / \mathrm{cm}$. The maximum value was recorded at station S1 during the rainy season. This low conductivity was linked to an increase in inland water supplies (Djibi and Bété rivers, runoff). Our conductivity values are lower than those of Kouamenanmoise [20]. Theseauthorsreportedvalues that vary between 3200 and $16700 \mu \mathrm{S} / \mathrm{cm}$ in the Ebrié lagoon. This difference could be due to the pronounced influence of the Atlantic Ocean on this lagoon.The statistical analysis (ANOVA) shows that there is no significant difference ( $>0.05)$ between seasons in temperature, $\mathrm{pH}$ and conductivity. The seasonal variations are not verypronounced. This is the character of the equatorial climate [21, 22].The waters of the Aghien Lagoon are oxygenated throughout the year. The percentage of dissolved oxygen shows minimum values $(63.91 \pm 22.28-82.18 \pm 15.96 \%)$ in the rainy season and maximum values $(85.16 \pm 10.01-100.22 \pm 16.71 \%)$ in the dry season. ANOVA analysis showed that there is a significant difference $(\mathrm{p}<0.05)$ between seasons for dissolved oxygen in stations S1, S2, S5, S6 and S8. The percentage of dissolved oxygen was high during the rainy season in these stations. The very high fluctuations of the dissolved oxygen values at the different stations are linked to the phenomena of enrichment (photosynthesis and exchanges with the atmosphere) and consumption (respiration and oxidation of organic matter) [23]. Seasonal turbidity values ranged between $21.76 \pm 5.15$ and $31.77 \pm 17.87$ NTU in the dry season and between $16.74 \pm 27.61$ and $41.05 \pm 37.65$ in the rainy season. Seasonal concentrations of TSS range from $8.72 \pm 3.52$ to 
$31.18 \pm 52.18 \mathrm{mg} / \mathrm{L}$. Values are high during the wet season and low during the dry season in all stations. Turbidity and TSS did not show significant inter-seasonal variation $(\mathrm{p}>0.05)$ in all stations except for station S7. This station (S7) exhibits significantly elevated turbidity and TSS during the wet season. These high values during the wet season can be justified by high anthropogenic activity generating high levels of suspended matter and by river arrivals, runoff [24]. They are generally below the permissible limit determined by international standard [25] which is $30 \mathrm{mg} / \mathrm{L}$.

Table II: Seasonal variation in the physico-chemical parameters values of the waters of the Aghien lagoon from June 2014 to May 2015

\begin{tabular}{|l|l|l|l|l|l|l|l|}
\hline & & Parameters & & & & & \\
\hline Stations & seasons & $\mathrm{T}^{\circ} \mathrm{C}$ & $\mathrm{pH}$ & Tur & Cond & TSS & $\mathrm{O}_{2}$ \\
\hline S1 & RS & $28.52 \pm 1.1$ & $7.47 \pm 0.38$ & $40.95 \pm 50.39$ & $109.12 \pm 65.22$ & $18.42 \pm 13.08$ & $71.15 \pm 16.06^{\mathrm{a}}$ \\
\hline & DS & $26.32 \pm 3.92$ & $7.62 \pm 0.70$ & $28.93 \pm 2.54$ & $71,43 \pm 12.29$ & $14 \pm 2.97$ & $95.5 \pm 17.84^{\mathrm{b}}$ \\
\hline S2 & RS & $28.67 \pm 1.32$ & $7.17 \pm 0.65$ & $38.91 \pm 52.99$ & $72.32 \pm 13.14$ & $14.03 \pm 14.56$ & $63.92 \pm 22.28^{\mathrm{a}}$ \\
\hline & DS & $26.37 \pm 4.1$ & $7.58 \pm 0.75$ & $21.76 \pm 5.15$ & $67.18 \pm 2.76$ & $11.47 \pm 5.99$ & $91.83 \pm 15.39^{\mathrm{b}}$ \\
\hline S3 & RS & $28.73 \pm 1.01$ & $7.6 \pm 1.00$ & $38.9 \pm 52.7$ & $73.07 \pm 12.3$ & $14.43 \pm 7.28$ & $78.48 \pm 21.97$ \\
\hline & DR & $27.45 \pm 2.36$ & $7.92 \pm 0.57$ & $31.67 \pm 17.87$ & $66.97 \pm 5.66$ & $11.2 \pm 5.6$ & $97.83 \pm 17.59$ \\
\hline S4 & RS & $29.35 \pm 2.57$ & $7.65 \pm 1.11$ & $36.83 \pm 47.70$ & $63.1 \pm 29.93$ & $27.13 \pm 42.86$ & $76.6 \pm 15.60$ \\
\hline & DS & $27.37 \pm 2.55$ & $7.43 \pm 0.82$ & $29.77 \pm 5.079$ & $63.15 \pm 9.01$ & $12.78 \pm 5.82$ & $91.17 \pm 15.92$ \\
\hline S5 & RS & $28.98 \pm 2.37$ & $7.87 \pm 1.18$ & $37.77 \pm 55.64$ & $71.62 \pm 13.69$ & $13.53 \pm 17.38$ & $77.53 \pm 16.74^{\mathrm{a}}$ \\
\hline & DS & $27.52 \pm 2.30$ & $7.73 \pm 0.65$ & $30.08 \pm 5.13$ & $66.78 \pm 2.40$ & $10.3 \pm 4.51$ & $100.22 \pm 16.71^{\mathrm{b}}$ \\
\hline S6 & RS & $28.7 \pm 2.12$ & $7.58 \pm 1.33$ & $16.74 \pm 27.61$ & $71.83 \pm 14.08$ & $15.73 \pm 17.85$ & $69.62 \pm 10.37^{\mathrm{a}}$ \\
\hline & DS & $27.12 \pm 2.45$ & $7.47 \pm 0.76$ & $29.9 \pm 4.55$ & $67.48 \pm 2.59$ & $7.88 \pm 7.2$ & $89.25 \pm 15.12^{\mathrm{b}}$ \\
\hline S7 & RS & $29.35 \pm 3.01$ & $7.85 \pm 1.44$ & $36.83 \pm 30.96^{\mathrm{a}}$ & $67.53 \pm 15.99$ & $17.23 \pm 8.25^{\mathrm{a}}$ & $75.37 \pm 20.08$ \\
\hline & DS & $28.43 \pm 4.76$ & $7.73 \pm 0.65$ & $26.94 \pm 6.11^{\mathrm{b}}$ & $68.35 \pm 3.49$ & $7.83 \pm 4.93^{\mathrm{b}}$ & $97.5 \pm 17.20$ \\
\hline S8 & RS & $29.13 \pm 2.62$ & $7.5 \pm 1.33$ & $36.74 \pm 45.87$ & $71.98 \pm 13.4$ & $31.18 \pm 52.18$ & $75.03 \pm 12.66^{\mathrm{a}}$ \\
\hline & DS & $26.87 \pm 2.11$ & $6.95 \pm 0.67$ & $31.2 \pm 7.04$ & $67.85 \pm 5.78$ & $14.05 \pm 6.77$ & $91.5 \pm 11.84^{\mathrm{b}}$ \\
\hline S9 & RS & $29.28 \pm 3.22$ & $8.03 \pm 1.17$ & $34.48 \pm 27.17$ & $68.95 \pm 12.14$ & $17.23 \pm 11.26$ & $82.18 \pm 15.96$ \\
\hline & DS & $26.83 \pm 2.63$ & $7.53 \pm 0.71$ & $26.57 \pm 8.67$ & $67.03 \pm 5.6$ & $13.2 \pm 8.94$ & $93.5 \pm 15.17$ \\
\hline S10 & RS & $29.77 \pm 3.56$ & $7.97 \pm 0.97$ & $30.87 \pm 38.29$ & $72.43 \pm 13.79$ & $13.6 \pm 9.34$ & $78.42 \pm 13.92$ \\
\hline & DS & $27.38 \pm 2.67$ & $7.42 \pm 0.77$ & $26.51 \pm 8.41$ & $66.4 \pm 4.39$ & $8.72 \pm 3.52$ & $96.67 \pm 14.99$ \\
\hline S11 & RS & $29.07 \pm 2.56$ & $7.3 \pm 0.64$ & $41.05 \pm 37.65$ & $75.88 \pm 21.31$ & $21.12 \pm 17.01$ & $68.92 \pm 17.23$ \\
\hline & DS & $26.48 \pm 2.36$ & $7.32 \pm 0.53$ & $28.95 \pm 7.31$ & $71.58 \pm 9.42$ & $17.33 \pm 4.96$ & $85.17 \pm 10.01$ \\
\hline
\end{tabular}

The values with $\mathrm{a}, \mathrm{b}, \mathrm{c}$ in superscript show a difference between seasons $(\mathrm{p}<0.05)$

RS ;rainy season DS ; dry season

\section{2- Nutrient salts}

The seasonal concentrations of nutrient salts (nitrate, nitrite and orthophosphate) from June 2014 to May 2015 in the water of the Aghien Lagoon are shown in Table III. Seasonal concentrations of nutrient salts in water $(\mathrm{mg} / \mathrm{L})$ ranged from $0.01 \pm 0.00$ to $0.15 \pm 0.05$ for $\mathrm{NO}_{2^{-}} ; 0.49 \pm 0.58$ and $1.93 \pm 1.34$ for $\mathrm{NO}_{3^{-}} ; 0.06 \pm$ 0.03 and $1.90 \pm 4.46$ for $\mathrm{PO}_{4}{ }^{3}-$. Seasonal variations showed a significant difference $(\mathrm{p}<0.05)$ for nitrate in $\mathrm{S} 2$, S5, S9 and S11 stations. These stations recorded a high rate of nitrate during the rainy season. There was no significant difference between seasons for nitrite and orthophosphate in all stations except in station S1. This station $(\mathrm{S} 1)$ recorded a peak orthophosphate $(1.90 \pm 4.46 \mathrm{mg} / \mathrm{L})$ during the dry season. These low nutrients salt contents are mainly due to the large presence of phytoplankton in the environment. Our values are low compared to the values recommended by the coastal water quality assessment system [26] which are $10 \mathrm{mg} / \mathrm{L}$ for nitrate; $0.3 \mathrm{mg} / \mathrm{L}$ for nitrite and $0.5 \mathrm{mg} / \mathrm{L}$ for orthophosphate.

Table III: Seasonal variation in Nutrient Salts in the Aghien Lagoon from June 2014 to May 2015

\begin{tabular}{|l|l|l|l|l|l|l|}
\hline & Nutrient salts & & & & \\
\hline & $\mathrm{NO}_{3}{ }^{-}$ & & $\mathrm{NO}_{2}{ }^{-}$ & & $\mathrm{PO}_{4}{ }^{3-}$ & \\
\hline Stations & $\mathrm{RS}$ & $\mathrm{DS}$ & $\mathrm{RS}$ & $\mathrm{DS}$ & $\mathrm{RS}$ & $\mathrm{DS}$ \\
\hline S1 & $1.49 \pm 1.13$ & $0.98 \pm 1.00$ & $0.08 \pm 0.10$ & $0.01 \pm 0.09$ & $0.15 \pm 0.75^{\mathrm{a}}$ & $1.90 \pm 4.46^{\mathrm{b}}$ \\
\hline S2 & $1.41 \pm 1.14^{\mathrm{a}}$ & $0.92 \pm 0,82^{\mathrm{b}}$ & $0.05 \pm 0.09$ & $0.01 \pm 0.00$ & $0.07 \pm 0.06$ & $0.07 \pm 0.03$ \\
\hline S3 & $1.21 \pm 1.12$ & $0.72 \pm 0.57$ & $0.06 \pm 0.09$ & $0.02 \pm 0.00$ & $0.21 \pm 0.30$ & $0.07 \pm 0.04$ \\
\hline S4 & $1.28 \pm 0.91$ & $0.94 \pm 0.72$ & $0.06 \pm 0.06$ & $0.02 \pm 0.07$ & $0.08 \pm 0.06$ & $0.25 \pm 0.4$ \\
\hline S5 & $0.97 \pm 1.09^{\mathrm{a}}$ & $0.92 \pm 0.35^{\mathrm{b}}$ & $0.06 \pm 0.10$ & $0.02 \pm 0.04$ & $0.06 \pm 0.07$ & $0.08 \pm 0.02$ \\
\hline S6 & $1.27 \pm 1.23$ & $0.61 \pm 0.66$ & $0.06 \pm 0.09$ & $0.01 \pm 0.02$ & $0.07 \pm 0.07$ & $0.08 \pm 0.02$ \\
\hline S7 & $1.44 \pm 0.82$ & $0.80 \pm 0.92$ & $0.05 \pm 0.05$ & $0.01 \pm 0.01$ & $0.20 \pm 0.29$ & $0.07 \pm 0.02$ \\
\hline S8 & $1.34 \pm 1.5$ & $0.49 \pm 0.58$ & $0.06 \pm 0.09$ & $0.02 \pm 0.02$ & $0.08 \pm 0.06$ & $0.08 \pm 0.01$ \\
\hline S9 & $1.61 \pm 1.52^{\mathrm{a}}$ & $0.79 \pm 0.57^{\mathrm{b}}$ & $0.15 \pm 0.05$ & $0.01 \pm 0.30$ & $0.09 \pm 0.04$ & $0.06 \pm 0.03$ \\
\hline S10 & $1.93 \pm 1.34$ & $0.66 \pm 1.67$ & $0.08 \pm 0.06$ & $0.02 \pm 0.11$ & $0.06 \pm 0.04$ & $0.07 \pm 0.02$ \\
\hline S11 & $1.73 \pm 1.37^{\mathrm{a}}$ & $0.78 \pm 0.49^{\mathrm{b}}$ & $0.05 \pm 0.04$ & $0.02 \pm 0.06$ & $0.13 \pm 0.11$ & $0.07 \pm 0.04$ \\
\hline
\end{tabular}

The values with $a, b, c$ in superscript show a difference between seasons $(p<0.05)$

RS ;rainy season DS ; dry season 


\section{3- COD, $\mathrm{BOD}_{5}$ and $\mathrm{COD} / \mathrm{BOD}_{5}$}

The seasonal concentrations values of $\mathrm{COD}, \mathrm{BOD}_{5}$ and the calculated $\mathrm{COD} / \mathrm{BOD}_{5}$ ratio are presented in Table IV. Concentrations in $\mathrm{mg}$ of $\mathrm{O}_{2} / \mathrm{L}$ of $\mathrm{COD}$ and $\mathrm{BOD}_{5}$ are between $19.53 \pm 21.55$ and $59.35 \pm 41.28$ and between $11.40 \pm 9.48$ and $26.02 \pm 23.75$ respectively. The $\mathrm{COD} / \mathrm{BOD}_{5}$ ratio varied from 1.53 to 2.75 . This high rate of $\mathrm{COD}$ and $\mathrm{BOD}_{5}$ could be due to the discharge of wastewater directly into the lagoon by local residents [27]. And the large supply of wastewater by the tributaries. The coefficient $\left(1.53-2.75 \mathrm{mg} \mathrm{O}_{2} / \mathrm{L}\right)$ of the $\mathrm{COD} / \mathrm{BOD}_{5}$ ratio of the Aghien lagoon confirmed the absence of industrial discharge in the lagoon and the ease of biodegradability [28]. It was a predominant organic effluent (heavily loaded with biodegradable materials). This ratio $\left(\mathrm{COD} / \mathrm{BOD}_{5}\right.$ ) also confirms that the water in the Aghien lagoon is subjected to domestic waste water pollution [29]. Our values are higher than the values recommended by the coastal water quality assessment system [26] for human consumption, which are $30 \mathrm{mg} / \mathrm{L}$ for COD; $6 \mathrm{mg} / \mathrm{L}$ for BOD.

Table IV :Seasonal variation in COD and $\mathrm{BOD}_{5}$ in the Aghien lagoon waters from June 2014 to May2015

\begin{tabular}{|l|l|l|l|l|l|l|}
\hline & COD & & BOD $_{5}$ & & COD/BOD $_{5}$ & \\
\hline Stations & RS & DS & RS & DS & RS & DS \\
\hline S1 & $27.78 \pm 33.68$ & $26.95 \pm 22.92$ & $12.57 \pm 15.78$ & $16.89 \pm 6.47$ & 2.20 & 1.59 \\
\hline S2 & $19.53 \pm 21.55$ & $24.03 \pm 19.03$ & $12.01 \pm 9.79$ & $12.57 \pm 7.12$ & 1.61 & 1.91 \\
\hline S3 & $21.78 \pm 35.29$ & $29.03 \pm 14.71$ & $14.20 \pm 13.75$ & $14.12 \pm 4.49$ & 1.53 & 2.06 \\
\hline S4 & $36.83 \pm 21.40$ & $20.48 \pm 23.60$ & $15.50 \pm 8.63$ & $12.57 \pm 5.84$ & 2.38 & 1.63 \\
\hline S5 & $21.13 \pm 23.19$ & $25.05 \pm 20.86$ & $11.40 \pm 9.48$ & $14.77 \pm 3.78$ & 1.85 & 1.70 \\
\hline S6 & $35.43 \pm 44.69$ & $38.52 \pm 23.71$ & $16.51 \pm 16.75$ & $18.99 \pm 7.20$ & 2.15 & 2.03 \\
\hline S7 & $55.42 \pm 41.90$ & $27.50 \pm 22.51$ & $20.13 \pm 16.72$ & $15.94 \pm 6.00$ & 2.75 & 1.3 \\
\hline S8 & $59.35 \pm 41.28$ & $42.87 \pm 47.40$ & $22.52 \pm 16.63$ & $26.02 \pm 23.75$ & 2.64 & 1.65 \\
\hline S9 & $45.95 \pm 52.49$ & $32.48 \pm 28.19$ & $18.43 \pm 18.87$ & $17.10 \pm 6.39$ & 2.49 & 1.90 \\
\hline S10 & $29.65 \pm 23.69$ & $37.50 \pm 35.37$ & $12.33 \pm 8.06$ & $19.62 \pm 9.36$ & 2.41 & 1.91 \\
\hline S11 & $51.80 \pm 32.78$ & $41.58 \pm 26.61$ & $23.05 \pm 21.06$ & $21.99 \pm 13.27$ & 2.25 & 1.89 \\
\hline
\end{tabular}

\subsection{Typology of the Aghien Lagoon}

The typology of the Aghien Lagoon was established on the basis of a Principal Component Analysis (PCA). In the projection of the variables on the axes (Fig. 2), the first component (Fact 1) contributes with $30.59 \%$ inertia and is defined in the positive side by the hydrogen potential and the percentage of dissolved oxygen. On the negative side axis 1 is defined by TSS, COD and $\mathrm{BOD}_{5}$. with a $24.49 \%$ inertia, the second component (Fact 2) is defined on the positive side by temperature and conductivity; On the negative side by the orthophosphate. The factorial map of the stations associated with the circle of correlation of the variables defines three types of water on the Aghien lagoon. The first type of water (I) found in stations S8 and S11 was characterized by high concentrations of TSS, $\mathrm{BOD}_{5}$ and $\mathrm{CDO}$. The second type of water (II) found in the stations S3, S4, S5, S6, S7, S9 and S10 was characterized by high levels of dissolved oxygen with warm and basic waters close to the characteristics of safe drinking water. This is probably due to the location of these stations far from the disturbance caused by river arrivals (the Djibi, Bété and La Mé rivers). The third type of water (III) found in the stations S1 and S2 was characterized by high phosphate levels and high conductivity. 

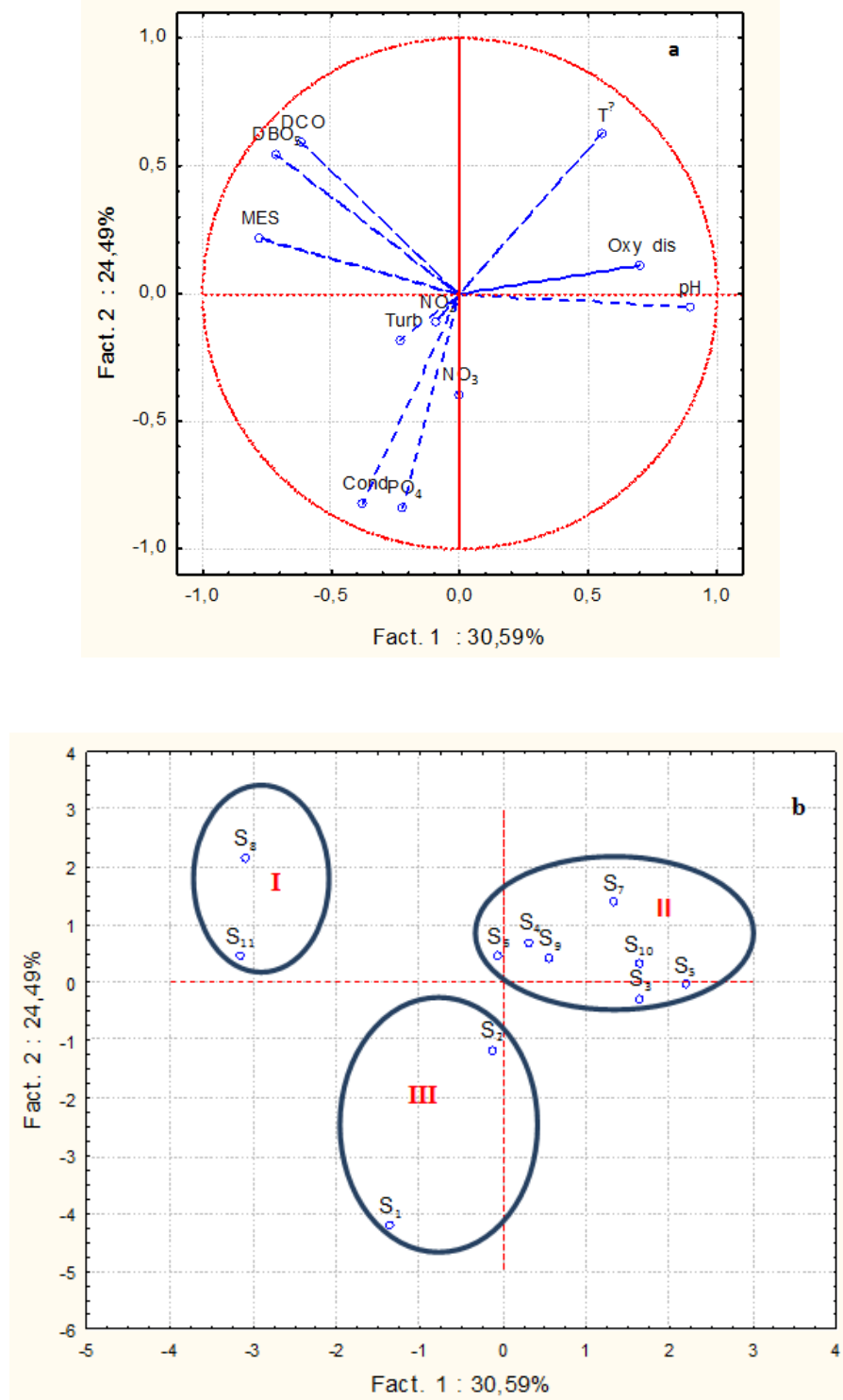

Fig 2:Projection of variables and stations on F1 and F2 axes. ( $\mathrm{a}=$ circle of the correlation of the variables, $\mathrm{b}=$ the factorial map of the stations).

\section{Conclusion}

This study contributed to the evaluation of the Aghien Lagoon water quality while allowing us to determine the typology. Mean values of physico-chemical parameters and nutrient salts during both seasons (wet and dry) are generally below the standard values recommended by the World Health Organization and the coastal quality assesment system. The $\mathrm{COD} / \mathrm{BOD}_{5}$ ratio showed that the Aghien Lagoon is polluted by the easily biodegradable organic matter. The Principal Component Analysis (P.C.A) of the data set made it possible to define three different types of water on the Aghien Lagoon. The waters of the stations S3, S4, S5, S6, S7, S9 and S10 are close to the characteristics of drinking water. On the whole, the waters of the Aghien Lagoon could be used for the production of drinking water after treatment.

\section{References Bibliographiques}

[1]. Berton Y.O: L'approvisionnement en eau des populations rurales au Congo-Brazzaville Cahier d'Outre-Mer p. 7-30. 2010.

[2]. Dufour J: L'eau douce se raréfie : Un bilan hydrique mondial. Conflits ou coopération?http://www.mondialisation.ca/leau-doucese-rarefie-un-bilan-hydrique-mondial-conflits-ou-cooperation/5448276?print=1 consulté le 901 2017.2015.

[3]. OMS: La santé et les services d'approvisionnement en eau de boisson salubre et d'assainissementde base, http://www.who.int/water_sanitation_health/mdg1/fr/. Consulté le 17 janvier 2015.p 1. 2015.

[4]. WWAP(Programme mondial pour l'évaluation des ressources en eau): Rapport mondial des Nations Unies.2016

[5]. Bertola M: Ressources : la Terre va-t-elle manquer d'eau douce? Science actualité.fr consulté le 901 2017.www.citesciences.fr/archives/science-actualites. le 02/10/2003

[6]. Redjem H., Azzeddine H.: Le déficit d'eau en Algérie : Une situation alarmante. Desalination 137 : 215-218.2001 
[7]. Tia L., Séka G: «Acteurs privés et approvisionnement en eau potable des populations de la commune d'Abobo (Côte d'Ivoire)». Revue canadienne de géographie tropicale/Canadian journal of tropical geography [En ligne], Vol. (2) 2. Mis en ligne le 15 novembre 2015, pp. 15-28. URL: http://laurentienne.ca/rcgt. 2015.

[8]. SOGREAH: Etude de la gestion et de la protection de la nappe assurant l'alimentation en eau potable d'Abidjan. Étude sur modèle mathématique. Rapport d'étude de phase 1, 2, 3, et 4.BNETD. décembre 1996.

[9]. Claude D, Ibrahima D, Yves S, M'bé A, Zamblé ZB., Jean-Pierre T, Bertin DY,Gilbert K, Jean-Claude C, Alain D.: Carte géologique de la Côte d'Ivoire à1/200 000, 1ère Edn, Feuille GRAND BASSAM, Direction de la Géologie, Abidjan, Côte d'Ivoire. 1992.

[10]. Humbert J.F. : Rapport sur la mission « lagune Aghien ». Rapport d'expertise, AFD-MINEF-SODECI-C2D, p 25.2012.

[11]. Rodier J: L'analyse de l'eau naturelle, eaux résiduaires, eau de mer, 8 ième éd. Denod, Paris, 1.rural africain. PS-Eau, collection Etudes et travaux, éditions du GRET, Ministère des Affaires. 1996.

[12]. Murphy J, Ryley J. :A modified single solution method for the determination of phosphate in natural waters. Anal.Chim. Acta, 27: 31-36.1962.

[13]. NF T90-101-2001:qualité de l'eau - détermination de la demande chimique en oxygène (DCO).2001.

[14]. APHA.: Standard Methods for Water and Wastewater Examination. 20 éme éd., American Public Health Association, Washington. 1998

[15]. Kouassi A.M: Hydrochimie et qualité des eaux de deux lagunes tropicales de Cote d'Ivoire (Ebrie, Grand Lahou).Thèse de Doctorat, Universite de Cocody,. Abidjan, p 147.2005.

[16]. Groga N.: Structure, fonctionnement et dynamique du phytoplancton dans lelac de Taabo (Côte d'Ivoire), thèse unique, Université de Toulouse, p 224.2012.

[17]. Makhoukh M., Sbaa M.,Berrahou A., Van Clooster M.: contribution a l'étude physico-chimique des eaux superficielles de l'oued moulouya (maroc oriental) Larhyss Journal, ISSN 1112-3680, nº 09, Décembre 2011, pp. 149-169.2011.

[18]. Moumouni D.M.H. :Caractéristiques physico-chimiques, bactériologiques et impact sur les eaux de surface et les eaux souterraines. Thèse de doctorat, université de Bamako, pp. 135.2005.

[19]. Lynda E, Tchirioua E, Jules NK., Toussaint D.: Variations temporelles des paramètres physicochimiques et biotiques de deux écosystèmes aquatiques de la lagune Ebrié. European Journal of ScientificResearch, 58(3): 414-422.2011.

[20]. Kouamenan N.M.: Variation Spatio-Temporelle Des Parametres Physico-Chimiques Et Des Sels Nutritifs Dans Les Secteurs IV Et V De La Lagune Ebrie. Memoire de Master II, Université Félix Houphouët Boigny, p 50.2006.

[21]. Lemoalle J.: La diversité des milieux aquatiques. In: Les poissons des eaux continentales africaines : diversité, écologie, utilisation par l'homme (Lévêque C. et Paugy D., Editeurs), IRD, Paris, 11-30 pp.2006.

[22]. Coulibaly S.: Bioaccumulation des métaux lourds et effet biologique induits chez SaratherodonMelanotheronRuppell, 1852 Pêche dans La Baie de Bietri En Lagune Ebrie (Cote d'Ivoire), thèse de Doctorat $3^{\text {ième }}$ cycle, Université NanguiAbrogoua ,142p. 2013.

[23]. El Morhit M.: Hydrochimie, éléments traces métalliques et incidence écotoxicologique sur les différentes composantes d'un écosystème estuarien (Bas Loukkos). Thèse de Doctorat, Université Mohammed 5 Agdal, Raba, Maroc, p 157.2009.

[24]. Yao K.M., Métongo S.B., Trokourey A., Yobou B.,: Assessment of sediments contamination by heavy metals in a tropical lagoon urban area (Ebrié lagoon, Côte d'Ivoire).International Journal of Biological and Chimical Sciences, 3: 755-770.2009.

[25]. OMS: Guidelines for drinking-water quality. Vol. 1, recommandations, 3rd ed., World Health Organization, Geneva.2001.

[26]. Système d'évaluation de la qualité de l'eau des cours d'eau : Grilles d'évaluation SEQ-EAU (version 2), MEDD \& Agences de l'eau, p. 40.2003.

[27]. DèdjihoA.C., Mama D., Tomètin L., Nougbodé I.,Chouti W., Sohounhloué D.C.K., Boukari M.: Evaluation de la qualité physico-chimique de certains tributaires d'eaux usées du lac Ahémé au Bénin. Journal of applied Biosciences 70 : 5608-5616.2013.

[28]. Boutayeb M., Bouzidi A., Fekhaoui M. : Etude de la qualité physico-chimique des eaux usées brutes de cinq villes de la région de la Chaouia - Ouardigha (Maroc).Bulletin de l'Institut Scientifique, Rabat, section Sciences de la Vie, n 34 (2), p. $145-150.2012$.

[29]. N'diaye D.A., Kankou.O.A.S.O.M., Lo.B., Namr.I.K.: Etude de la qualité physico-chimique des eaux usées brutes de la ville de Nouakchott, Science Lib Edition Mersenne vol 3, N 110703.2011. 